\title{
PENGARUH TINGKAT EC (ELECTRICAL CONDUCTIVITY) TERHADAP PERTUMBUHAN TANAMAN SAWI (Brassica juncea L.) PADA SISTEM INSTALASI AEROPONIK VERTIKAL
}

\section{EFFECT OF EC (ELECTRICAL CONDUCTIVITY) LEVEL ON GROWTH OF MUSTARD (Brassica juncea L.) IN VERTICAL AEROPONIC SYSTEM}

\author{
Pusdima Rahma Pratiwi, M. Subandi, dan Eri Mustari \\ Jurusan Agroteknologi Fakultas Sains dan Teknologi \\ UIN Sunan Gunung Djati Bandung, JI. AH. Nasution 105 Bandung 40614 \\ Korespondensi: ms24454@yahoo.com
}

Diterima 30 Januari 2015 /Disetujui 27 April 2015

\begin{abstract}
ABSTRAK
Kebutuhan akan tanaman sawi semakin meningkat, sehingga diperlukan teknologi yang dapat memaksimalkan hasil serta memperbaiki teknik budidaya, salah satunya teknik budidaya aeroponik vertikal. Penelitian ini bertujuan untuk mengetahui respon pertumbuhan tanaman sawi yang terbaik terhadap pengaruh tingkat EC pada larutan nutrisi. Penelitian ini dilaksanakan di daerah Bekasi Timur dengan ketinggian $25 \mathrm{~m}$ di atas permukaan laut, dimulai pada bulan April 2014 sampai Juli 2014. Rancangan yang digunakan adalah Rancangan Acak Kelompok dengan 4 perlakuan yaitu A (Tingkat EC $1 \mathrm{mS} \mathrm{cm}^{-1}$ ), B (Tingkat EC $1,5 \mathrm{mS} \mathrm{cm}^{-1}$ ), C (Tingkat EC $2 \mathrm{mS} \mathrm{cm}^{-1}$ ), dan D (Tingkat EC $2,5 \mathrm{mS} \mathrm{cm}^{-1}$ ) dengan diulang sebanyak 4 kali. Hasil penelitian menunjukkan bahwa tingkat EC berpengaruh terhadap tinggi tanaman sawi pada umur 14 dan 18 hst, luas daun pada umur 26 dan 30 hst, panjang akar pada umur 30 hst, dan bobot basah pada umur $30 \mathrm{hst}$. Tingkat EC $2,5 \mathrm{mS} \mathrm{cm}^{-1}$ memberikan pengaruh baik terhadap bobot basah.
\end{abstract}

Kata kunci: Instalasi Aeroponik Vertikal, Pertumbuhan, Sawi, Tingkat EC

\begin{abstract}
The increasing need of mustard require technologies that can maximize result and improve cultivation, one of them is aeroponic vertical cultivation technique. This research aimed to know the best response of mustard growth on influence of nutrient EClevel. This research was carried out in Bekasi Timur with altitude of $25 \mathrm{~m}$ above sea level, form April 2014 to July 2014. The design used was Randomized Block Design with 4 treatments that $\mathrm{A}$ ( $\mathrm{EC}$ level $1 \mathrm{mS} \mathrm{cm}^{-1}$ ), $\mathrm{B}$ (EC level 1,5 $\mathrm{mS} \mathrm{cm}^{-1}$ ), C (EC level $2 \mathrm{mS} \mathrm{cm}^{-1}$ ), and D (EC level $2,5 \mathrm{mS} \mathrm{cm}^{-1}$ ) with 4 replications. The results showed that EC level affected on plant height at 14 and 18 dap, leaf area at 26 and 30 dap, root length at 30 dap, and wet weight at the age of 30 dap. The EC level 2,5 mS cm had better effect on wet weight.
\end{abstract}

Key words : EC level, Growth, Mustard, Vertical Aeroponic Installation 


\section{PENDAHULUAN}

Sawi (Brassica juncea L.) termasuk tanaman sayuran daun dari keluarga Cruciferae yang mempunyai nilai ekonomis tinggi. Dalam $100 \mathrm{~g}$ sawi nilai gizinya adalah protein 2,3 g; lemak 0,3 g; karbohidrat 4,0 g; Ca 220,0 mg; P 38,0 mg; Fe 2,9 mg; vitamin A $1.940 \mathrm{mg}$; vitamin B 0,09 mg; dan vitamin C $102 \mathrm{mg}$. Kandungan gizi pada sayuran terutama vitamin dan mineral tidak dapat disubtitusi melalui makanan pokok. Di Indonesia tanaman sawi merupakan jenis sayuran yang digemari banyak orang, namun produksinya masih tergolong rendah (Manurung, 2011).

Peningkatan hasil tanaman hortikultura dapat dilakukan dengan teknik budidaya yang memiliki efisiensi dan efektivitas yang tinggi. Salah satu teknik budidaya yang diharapkan dapat meningkatkan hasil tanaman sawi adalah hidroponik. Terdapat beberapa teknik dalam menerapkan budidaya sayuran secara hidroponik, diantaranya yaitu teknik hidroponik sistem terapung, Nutrient Film Technique (NFT), dan aeroponik (Jones, 2005).

Sistem aeroponik memiliki keunggulan yang tidak dimiliki oleh sistem hidroponik lainnya, yaitu tanaman lebih mudah menyerap nutrisi karena berukuran molekul kecil (Trubus, 2013). Perkembangan sistem hidroponik khususnya aeroponik yang terbaru adalah instalasi aeroponik vertikal. Sebuah sistem budidaya aeroponik yang penempatannya secara vertikal sejajar memungkinkan untuk budidaya tanaman di sebagian kecil ruangan (Luebbers dkk, 2012).

Beberapa faktor penting yang harus diperhatikan dalam budidaya aeroponik antara lain unsur hara, suplai oksigen, dan suplai air. Salah satu faktor penting yang mempengaruhikualitas unsur hara dalam budidaya aeroponik adalah Electrical Conductivity (EC). EC adalah ukuran dari jumlah garam yang terlarut dalam larutan nutrisi atau kepekatan pupuk dalam larutan hidroponik (Karsono dkk, 2002). Nilai EC dalam larutan mempengaruhi metabolism tanaman, yaitu dalam hal kecepatan fotosintesis, aktivitas enzim, dan potensi penyerapan ion-ion oleh akar. Kepekatan larutan nutrisi juga akan menentukan lama penggunaan larutan nutrisi dalam sistem aeroponik (Sutanto, 2002).

Berdasarkan uraian tersebut dalam upaya menghasilkan tanaman sawi yang berkualitas dengan menerapkan sistem budidaya hidroponik yaitu sistem instalasi aeroponik vertikal, perlu dilakukan penelitian mengenai "Pengaruh Tingkat EC terhadap Pertumbuhan Tanaman Sawi (Brassica juncea L.) pada Sistem Instalasi Aeroponik Vertikal," sehingga dapat diketahui tingkat EC optimum yang dapat menghasilkan tanaman sawi berkualitas.

\section{BAHAN DAN METODE}

Penelitian ini dilaksanakan pada Bulan April - Juli 2014 di daerah Bekasi Timur dengan ketinggian $25 \mathrm{~m}$ di atas permukaan laut. Penelitian ini menggunakan Rancangan Acak Kelompok (RAK) dengan 4 perlakuan yaitu $A$ (Tingkat EC $1 \mathrm{mS} \mathrm{cm}^{-1}$ ), B (Tingkat EC $1,5 \mathrm{mS} \mathrm{cm}^{-1}$ ), C (Tingkat EC $2 \mathrm{mS} \mathrm{cm}^{-1}$ ), dan $\mathrm{D}$ (Tingkat EC $2,5 \mathrm{mS} \mathrm{cm}^{-1}$ ) dengan diulang sebanyak 4 kali. Bahan dan alat yang digunakan dalam penelitian ini yaitu benih tanaman sawi (Brassica juncea L.) varietas Green Eagle, nutrisi AB Mix, air, dan rockwool serta instalasi aeroponik vertikal.

Tujuh hari sebelum penanaman, benih sawi disemai terlebih dahulu. Bersamaan 
dengan itu, larutan nutrisi $A B$ Mix dibuat dengan cara menambahkan air bersih ke dalam stok $A$ hingga menjadi 1 liter larutan stok $A$ dan menambahkan air bersih ke dalam stok $B$ hingga menjadi 1 liter larutan stok $B$, setelah itu aduk hingga benar-benar larut. Kemudian untuk membuat larutan EC $1 \mathrm{mS} \mathrm{cm}^{-1}$ menggunakan 5,4 ml larutan stok A dan 5,4 ml larutan stok B ke dalam 3 liter air bersih; larutan EC $1,5 \mathrm{mS} \mathrm{cm}^{-1}$ menggunakan 7,5 ml larutan stok $A$ dan 7,5 $\mathrm{ml}$ larutan stok $\mathrm{B}$ ke dalam 3 liter air bersih; larutan EC $2 \mathrm{mS} \mathrm{cm}^{-1}$ menggunakan $15 \mathrm{ml}$ larutan stok A dan $15 \mathrm{ml}$ larutan stok B ke dalam 3 liter air bersih; serta larutan EC 2,5 $\mathrm{mS} \mathrm{cm}{ }^{-1}$ menggunakan 21,3 ml larutan stok A dan 21,3 ml larutan stok B ke dalam 3 liter air bersih dan diaduk dengan rata.

Media tanam yang digunakan adalah rockwool yang diberikan larutan nutrisi $A B$ Mix sesuai dengan perlakuan. Pengecekan tingkat EC dan $\mathrm{pH}$ larutan nutrisi $A B$ Mix dilakukan setiap hari agar larutan nutrisi tersebut tetap sesuai dengan perlakuan.
Parameter pengamatan utama yang diamati pada penelitian ini meliputi tinggi tanaman $(\mathrm{cm})$, jumlah daun (helai), luas daun $(\mathrm{cm} 2)$, panjang akar $(\mathrm{cm})$, dan bobot basah tanaman (g). Parameter tinggi tanaman, jumlah daun, dan luas daun diamati pada umur tanaman 14 HST, 18 HST, 22 HST, 26 HST, dan 30 HST. Sedangkan untuk parameter lainnya dilakukan pada saat panen.

\section{HASIL DAN PEMBAHASAN}

\section{Tinggi Tanaman $(\mathrm{cm})$}

Hasil analisis menunjukkan perlakuan tingkat EC berpengaruh sangat nyata terhadap tinggi tanaman pada umur 14 HST dan berpengaruh nyata terhadap tinggi tanaman pada umur $18 \mathrm{HST}$, tetapi berpengaruh tidak nyata terhadap tinggi tanaman pada umur 22, 26, dan 30 HST (Tabel 1).

Tabel 1. Rataan Tinggi Tanaman Sawi $(\mathrm{cm})$ pada Berbagai Tingkat EC umur $14-30$ HST

\begin{tabular}{cccccc}
\hline \multirow{2}{*}{ Perlakuan } & \multicolumn{5}{c}{ Tinggi Tanaman pada umur (HST) } \\
\cline { 2 - 6 } & 14 & 18 & 22 & 26 & 30 \\
\hline $\mathrm{A}=\mathrm{EC} 1 \mathrm{mS} \mathrm{cm}^{-1}$ & $3,19 \mathrm{a}$ & $4,14 \mathrm{a}$ & $7,39 \mathrm{a}$ & $12,25 \mathrm{a}$ & $17,89 \mathrm{a}$ \\
$\mathrm{B}=\mathrm{EC} 1,5 \mathrm{mS} \mathrm{cm}^{-1}$ & $3,71 \mathrm{~b}$ & $4,62 \mathrm{~b}$ & $7,35 \mathrm{a}$ & $12,31 \mathrm{a}$ & $16,67 \mathrm{a}$ \\
$\mathrm{C}=\mathrm{EC} 2 \mathrm{mS} \mathrm{cm}^{-1}$ & $3,33 \mathrm{a}$ & $4,37 \mathrm{ab}$ & $7,46 \mathrm{a}$ & $11,75 \mathrm{a}$ & $16,52 \mathrm{a}$ \\
$\mathrm{D}=\mathrm{EC} 2,5 \mathrm{mS} \mathrm{cm}^{-1}$ & $3,65 \mathrm{~b}$ & $4,56 \mathrm{~b}$ & $7,71 \mathrm{a}$ & $12,46 \mathrm{a}$ & $17,35 \mathrm{a}$ \\
\hline
\end{tabular}

Keterangan: Angka yang diikuti huruf yang sama pada kolom yang sama menunjukkan berbeda tidak nyata berdasarkan DMRT 5\%

Berdasarkan data tersebut diduga bahwa pada awal pertumbuhan, tanaman sawi masih membutuhkan banyak unsur hara untuk pertumbuhan vegetatif sehingga tingkat EC mempengaruhi pertumbuhan vegetatif tanaman. Menurut penelitian Laelasari (2004), nilai EClarutan nutrisi yan sesuai dengan kebutuhan tanaman sawi yaitu sebesar $1,5-2,0 \mathrm{mS} \mathrm{cm}^{-1}$, dan nilai tolerannya sebesar $2,5 \mathrm{mS} \mathrm{cm}^{-1}$.

Respon tanaman terhadap tingkat EC dipengaruhi umur tanaman dan tahap pertumbuhan tanaman. Peran nitrogen pada fase vegetatif tanaman untuk pertambahan panjang serta pertumbuhan tanaman. Nitrogen berfungsi untuk memacu pertumbuhan pada fase vegetatif 
terutama daun dan batang (Lingga, 2005). Pada umur 22 HST kemungkinan tanaman sudah mulai masuk ke dalam masa senesen menuju fase generatif sehingga tingkat EC berpengaruh tidak nyata terhadap pertambahan panjang atau tinggi tanaman.
Hasil analisis menunjukkan perlakuan tingkat EC berpengaruh tidak nyata terhadap jumlah daun tanaman sawi pada umur 14 - 30 HST. Perkembangan jumlah daun dengan perlakuan tingkat EC $1,5 \mathrm{mS}$ $\mathrm{cm}^{-1}$ dan $2,5 \mathrm{mS} \mathrm{cm}^{-1}$ pada umur $26-30$ HST mengalami penurunan (Tabel 2).

\section{Jumlah Daun (helai)}

Tabel 2. Rataan Jumlah Daun Tanaman Sawi (helai) pada Berbagai Tingkat EC umur $14-30$ HST

\begin{tabular}{|c|c|c|c|c|c|}
\hline \multirow{2}{*}{ Perlakuan } & \multicolumn{5}{|c|}{ Jumlah Daun pada umur (HST) } \\
\hline & 14 & 18 & 22 & 26 & 30 \\
\hline $\mathrm{A}=\mathrm{EC} 1 \mathrm{mS} \mathrm{cm}^{-1}$ & $3,96 a$ & $5,46 a$ & $2,53 a$ & $6,79 a$ & $7,08 \mathrm{a}$ \\
\hline $\mathrm{B}=\mathrm{EC} 1,5 \mathrm{mS} \mathrm{cm}^{-1}$ & $4,08 a$ & $5,54 a$ & $2,49 a$ & $6,92 \mathrm{a}$ & $7,00 \mathrm{a}$ \\
\hline $\mathrm{C}=\mathrm{EC} 2 \mathrm{mS} \mathrm{cm}^{-1}$ & $4,04 a$ & $5,67 a$ & $2,49 a$ & $7,00 \mathrm{a}$ & $7,38 \mathrm{a}$ \\
\hline $\mathrm{D}=\mathrm{EC} 2,5 \mathrm{mS} \mathrm{cm}^{-1}$ & $4,33 a$ & $5,75 a$ & $2,51 \mathrm{a}$ & $7,12 \mathrm{a}$ & $7,13 \mathrm{a}$ \\
\hline
\end{tabular}

Keterangan: Angka yang diikuti huruf yang sama pada kolom yang sama menunjukkan berbeda tidak nyata berdasarkan DMRT $5 \%$

Menurut Devlin (1975), air sangat berperan penting dalam pertumbuhan tanaman, akan tetapi air juga dapat membatasi pertumbuhan. Jika jumlah air terlalu sedikit akan menimbulkan kekeringan pada tanaman. Tanaman yang mengalami kekurangan air, stomata daunnya menutup sebagai akibat menurunnya turgor sel daun sehingga mengurangi jumlah $\mathrm{CO}_{2}$ yang berdifusi ke dalam daun. Selain itu menutupnya stomata akan mengakibatkan laju transpirasi menurun. Menurunnya laju transpirasi akan mengurangi suplai unsur hara dari larutan nutrisi aeroponik ke tanaman, karena transpirasi pada dasarnya memfasilitasi laju aliran air, sedangkan nutrisi untuk pertumbuhan tanaman bercampur dengan air pada sistem aeroponik. Hal ini dapat menjelaskan mengapa tingkat EC berpengaruh tidak nyata terhadap jumlah daun tanaman sawi yang pada saat penelitian, pemberian larutan nutrisi masih kurang memenuhi kebutuhan tanaman sawi dalam masa pertumbuhannya.

\section{Luas Daun $\left(\mathrm{cm}^{2}\right)$}

Hasil analisis menunjukkan perlakuan tingkat EC berpengaruh tidak nyata terhadap luas daun pada umur 14 - 22 HST dan sangat berpengaruh nyata terhadap luas daun pada umur 26-30 HST (Tabel 3).

Tabel 3. Rataan Luas Daun Tanaman Sawi (cm2) pada Berbagai Tingkat EC umur 14 - 30 HST

\begin{tabular}{cccccc}
\hline \multirow{2}{*}{ Perlakuan } & \multicolumn{5}{c}{ Luas Daun pada umur (HST) } \\
\cline { 2 - 6 } & 14 & 18 & 22 & 26 & 30 \\
\hline $\mathrm{A}=\mathrm{EC} 1 \mathrm{mS} \mathrm{cm}^{-1}$ & $3,70 \mathrm{a}$ & $3,89 \mathrm{a}$ & $5,12 \mathrm{a}$ & $7,12 \mathrm{a}$ & $12,98 \mathrm{a}$ \\
$\mathrm{B}=\mathrm{EC} 1,5 \mathrm{mS} \mathrm{cm}^{-1}$ & $3,44 \mathrm{a}$ & $3,75 \mathrm{a}$ & $4,99 \mathrm{a}$ & $7,04 \mathrm{a}$ & $12,89 \mathrm{a}$ \\
$\mathrm{C}=\mathrm{EC} 2 \mathrm{~m} \mathrm{~cm}^{-1}$ & $3,47 \mathrm{a}$ & $3,84 \mathrm{a}$ & $5,07 \mathrm{a}$ & $7,26 \mathrm{a}$ & $13,07 \mathrm{a}$ \\
$\mathrm{D}=\mathrm{EC} 2,5 \mathrm{~m} \mathrm{~cm}^{-1}$ & $3,75 \mathrm{a}$ & $4,11 \mathrm{a}$ & $5,36 \mathrm{a}$ & $7,59 \mathrm{~b}$ & $13,39 \mathrm{~b}$ \\
\hline
\end{tabular}

Keterangan: Angka yang diikuti huruf yang sama pada kolom yang sama menunjukkan berbeda tidak nyata berdasarkan DMRT 5\% 
Secara fisiologis semakin lama umur tanaman maka indeks luas daun tanaman akan semakin besar karena terjadi pertumbuhan. Cahaya yang diterima tanaman dengan indeks luas daun besar akan lebih banyak dibandingkan dengan tanaman yang memiliki luas indeks daun kecil. Menurut Junita dkk (2002) indeks luas daun yang besar pada suatu lahan yang luas belum tentu menunjukkan bahwa setiap individu mampu menyerap energi matahari secara efektif. Hal ini terjadi karena antara daun yang satu dengan lainnya dapat saling menaungi, sehingga tidak mendapatkan sinar matahari secara penuh.

\section{Panjang Akar Tanaman (cm)}

Hasil analisis menunjukkan tingkat EC 1 $\mathrm{mS} \mathrm{cm}^{-1}$ dan tingkat EC $2,5 \mathrm{mS} \mathrm{cm}^{-1}$ berpengaruh tidak nyata terhadap panjang akar tanaman sawi sedangkan tingkat EC 1,5 $\mathrm{mS} \mathrm{cm}^{-1}$ dan tingkat EC $2 \mathrm{mS} \mathrm{cm} \mathrm{cm}^{-1}$ berpengaruh nyata (Tabel 4). Panjang akar tanaman sawi tertinggi terdapat pada ulangan ke-2 dengan perlakuan tingkat EC 2 $\mathrm{mS} \mathrm{cm}{ }^{-1}$.

Tabel 4. Pengaruh Panjang Akar Tanaman Sawi $(\mathrm{cm})$ terhadap Tingkat EC Perlakuan Panjang Akar Tanaman

\begin{tabular}{cc}
\hline Perlakuan & $\begin{array}{c}\text { Panjang Akar } \\
\text { Tanaman }(\mathrm{cm})\end{array}$ \\
\hline $\mathrm{A}=\mathrm{EC} 1 \mathrm{mS} \mathrm{cm}^{-1}$ & $6,70 \mathrm{a}$ \\
$\mathrm{B}=\mathrm{EC} 1,5 \mathrm{mS} \mathrm{cm}^{-1}$ & $8,92 \mathrm{c}$ \\
$\mathrm{C}=\mathrm{EC} 2 \mathrm{mS} \mathrm{cm}^{-1}$ & $8,72 \mathrm{~b}$ \\
$\mathrm{D}=\mathrm{EC} 2,5 \mathrm{mS} \mathrm{cm}^{-1}$ & $7,14 \mathrm{a}$ \\
\hline Keterangan: & Angka yang diikuti huruf yang \\
& sama pada kolom yang sama \\
& menunjukkan berbeda tidak nyata \\
berdasarkan DMRT 5\%
\end{tabular}

Pertumbuhan tanaman dengan sistem aeroponik vertikal ini memiliki hasil yang baik karena respirasi akar lancar dan menghasilkan banyak energi untuk pertumbuhan tanaman. Kebutuhan terhadap oksigen bagi sistem perakaran tanaman diperoleh dari sebagian akar yang tidak terkena semburan kabut larutan nutrisi (Morgan, 2000). Oksigen tetap diperoleh tanaman dari oksigen yang terlarut dalam larutan nutrisi, tetapi sebagian besar oksigen yang diserap tanaman diperoleh dari akar yang tidak terkena semburan kabut larutan nutrisi. Sedangkan sebagian akar yang terkena semburan kabut larutan nutrisi, menyerap unsur hara dan air yang diperlukan oleh tanaman. Sehingga oksigen, air, dan unsur hara yang diperlukan oleh tanaman dapat terpenuhi untuk pertumbuhan tanaman secara normal. Gangguan akar brupa kekurangan oksigen dapat mengakibatkan pertumbuhan tanaman yang tidak sempurna serta menyebabkan menurunnya hasil panen.

\section{Bobot Basah Tanaman (g)}

Hasil analisis menunjukkan perlakuan tingkat EC $1,5 \mathrm{mS} \mathrm{cm}^{-1}$ dan tingkat EC $2 \mathrm{mS}$ $\mathrm{cm}^{-1}$ berpengaruh tidak nyata sedangkan tingkat EC $1 \mathrm{mS} \mathrm{cm}^{-1}$ dan tingkat EC 2,5 mS $\mathrm{cm}^{-1}$ saling berpengaruh nyata (Tabel 5). Hasil bobot basah tertinggi terdapat pada ulangan 1 dengan perlakuan tingkat EC 2,5 $\mathrm{mS} \mathrm{cm}^{-1}$.

Tingkat EC $2,5 \mathrm{mS} \mathrm{cm}^{-1}$ berpengaruh sangat nyata terhadap bobot basah tanaman, hal ini dipengaruhi oleh keadaan daun yang dihasilkan. Jumlah daun pada komoditi sayuran daun berpengaruh pada bobot basah tanaman. Semakin banyak jumlah daun maka itu menunjukkan bobot basah yang juga meningkat. Selain itu luas daun juga berpengaruh pada bobot basah tanaman. Luas daun semakin lebar diikuti bobot basah yang tinggi (Perwitasari dkk, 2012). Berdasarkan penampilan tanaman 
sawi yang dihasilkan pada tingkat EC 2,5 mS $\mathrm{cm}^{-1}$ memiliki percabangan yang banyak dan luas daun yang tinggi dibandingkan dengan tanaman yang dihasilkan pada tingkat EC lainnya. Menurut Nurshanti (2010) bobot basah ditentukan oleh banyak percabangan dan daya tumbuh yang tinggi pada tanaman sawi atau caisim.

Tabel 5. Pengaruh Bobot Basah Tanaman Sawi (g) terhadap Berbagai Tingkat EC Perlakuan Bobot Basah Tanaman

\begin{tabular}{cc}
\hline Perlakuan & $\begin{array}{c}\text { Bobot Basah } \\
\text { Tanaman }(\mathrm{g})\end{array}$ \\
\hline $\mathrm{A}=\mathrm{EC} 1 \mathrm{mS} \mathrm{cm}^{-1}$ & $17,85 \mathrm{a}$ \\
$\mathrm{B}=\mathrm{EC} 1,5 \mathrm{mS} \mathrm{cm}^{-1}$ & $20,13 \mathrm{~b}$ \\
$\mathrm{C}=\mathrm{EC} 2 \mathrm{mS} \mathrm{cm}^{-1}$ & $22,37 \mathrm{~b}$ \\
$\mathrm{D}=\mathrm{EC} 2,5 \mathrm{mS} \mathrm{cm}^{-1}$ & $28,11 \mathrm{c}$ \\
\hline Keterangan: & Angka yang diikuti huruf yang \\
& sama pada kolom yang sama \\
menunjukkan berbeda tidak nyata &
\end{tabular}

\section{SIMPULAN}

1. Tingkat $\mathrm{EC}$ berpengaruh terhadap tinggi tanaman sawi pada umur 14 dan 18 HST, luas daun pada umur 26 dan 30 HST, panjang akar pada umur $30 \mathrm{HST}$, dan bobot basah pada umur 30 HST.

2. Tingkat EC $2,5 \mathrm{mS} \mathrm{cm}^{-1}$ memberikan pengaruh baik terhadap bobot basah.

\section{DAFTAR PUSTAKA}

Devlin, RM., dan FH. Witham. 1975. Plant Physiology. Rinelang book Corporation a Subsidiarey of Champion Reinhold inc: New York.

Jones, J. B. 2005. Hydroponics: A Practical Guide for the Soilless Grower. Second Edition. CRC Press. USA. 423p.
Junita, F., S. Muhartini, dan D. Kastono. 2002. Pengaruh Frekuensi Penyiraman dan Takaran Pupuk Kandang terhadap Pertumbuhan dan Hasil Pakchoi. Jurnal IImu Pertanian 2002, IX (1).

Karsono, S., Sudarmodjo, dan Y. Sutiyoso. 2002. Hidroponik Skala Rumah Tangga. Memanfaatkan Rumah dan Pekarangan. Depok: PT. Agromedia Pustaka.

Lingga, P. 2005. Hidroponik, Bercocok Tanam Tanpa Tanah. Jakarta: Penebar Swadaya.

Luebbers, T. and S. Hensley. 2012. Vertical Aeroponic Plant Growing System. United States: Patent Application Publication. US 2012/0297678 A1.

Manurung, R. F. H., 2011. Respon Pertumbuhan dan Produksi Tanaman Sawi (Brassica juncea L.) Terhadap Penggunaan Pupuk Anorganik Cair. Medan: Universitas Sumatera Utara.

Morgan, L. 2000. Are Your Plants Suffocating? The Importance of Oxygen in Hydroponics. The Growing Edge, Vol. 12(6): $50-54$.

Perwitasari, B., M. Tripatmasari, dan C. Wasonowati. 2012. Pengaruh Media Tanam dan Nutrisi terhadap Pertumbuhan dan Hasil Tanaman Pakchoi (Brassica juncea L) dengan Sistem Hidroponik. Jurnal Agrovigor Vol. 5(1): 14 - 25. Fakultas Pertanian. Universitas Trunojoyo Madura.

Sutanto, R., 2002. Penerapan Pertanian Organik. Permasyarakatan dan Pengembangannya. Penerbit Kanisius. Yogyakarta.

Trubus. 2013. Teknik Tanam Tanpa Tanah. No. 529 Edisi Desember 2013/XLIV. h. 20 $-23$. 